\title{
The Religious Dimension in Plural Schools: Institutional, Relational and Strategic Issues
}

\author{
Maddalena Colombo
}

Introduction: Cultural Change and the Role of Religion in Public
Schooling

This chapter is focused on religion as an element of the schooling process and aims at enlightening the main changes occurring in public schools as a consequence of the increasing pluralism and multi-ethnicity (Colombo, 2013), overall among students and their families, and the "new" consideration of religion (and religion education) within the school environment (Hobson, Edwards, 1999). The change is mainly due to a two-fold pushing factor:

- A demographic change, in all Europe the second-generation immigrant population brings into the school environment the reality of a multitude of faiths and worships, with more or less attachment in comparisons to their parents or to peers with a native background;

- A cultural change, the organization of public education in many countries lies on the secularization principle - which means that, when it comes to student's religion, it tends to be as neutral as possible. This goes along with an increasing "indifference" of young people to the family religious traditions and belonging, and the growth in the number of youngsters who are not believers, agnostic or religious recusants (Garelli, 2016). It is widely acknowledged that secularization brings about a privatization of the religious choice and observance, and an increase in religious illiteracy (Melloni, 2014; Cadeddu, Melloni, 2018).

Here, we want to discuss two consequences of this on public schooling. At an institutional level, pluralization through migration -especially after the last decade, with its threatening issues about religious fundamentalism and radicalization among people with an immigrant background- may have led many educators to change the focus of their discussions on religion at school; i.e. from a form of single faith religious teaching to a "non-confessional", inclusive, multi-faith approach, including learning about the religions of relatively newly established minorities such as Hindus, Sikhs and Muslims, as well as about Christianity and Judaism. Or, from a casual and mostly improvised reference to 
faith into the Human Studies curriculum, to a more structured inclusion of learning objects concerning religions as historic expressions of mankind, modern institutions and set of lively rituals that feature different people and States, etc. (Jackson, 2014 and 2016).

At a relational level, instead, the resurgence of religion (as "identity specific") among immigrant students and parents may have generated various kinds of reactions, both by majority and minority school agents, from discomfort to curiosity, from intolerance to intercultural solidarity. As sociologists of education, we have been interrogating about how this mixed educational landscape is going to be designed, as regards the main issues at stake when students' religion is visible: equity, integration, diversity management, citizenship and values education. Questions, such as "Are we in an equal, not discriminating, and peaceful environment because of the disappearance (or neutralization) of religion(s)?" and "Are we in a conflict arena, where religious worships, communitarian belonging and perception of social discrimination generate discussion, tensions and fight among students, teachers and parents?" become urgent. As well as the question about the strategy that schools with multi-ethnic groups of learners may adopt to reach their purposes better: "Must the public school teach more about religions, with the aim of making students aware of their own cultural roots and religious belongings? Or must it practice more laicism, avoiding to pervade teaching about religious contents and pursue the objective to give students tools for choice and identity building, across a neutral, non-religious, universalistic, curriculum?". In evidence, the response to such questions shows if a school can represent a "neutral space" for students, where diversities can respect one another independently of their roots or, instead, if it becomes a "common house", where students background is reciprocally questioned and recognized as a tool for growth.

Recently, Benadusi et al. (2017) stated that teaching religions in public institutions is still an open issue, because of the main associated risks of ideologization and "functionalization" of religion in mixed schools - facing interfaith conflicts, misunderstandings and negative stereotypes that are likely to rise where religious speech and practices take place. Although the majority of state school principals (elsewhere in Europe) seem to recommend to keep out from religious disputes and show the "secular self", many school professionals feel distress facing the negative externalities of the neutral school, and claim for better preparation to cope with cultural and religious clashes among students or with immigrant parents (Laborde, Silhol, 2018).

Taking religions as a fundamental part (among others) of the public debate on education is thus unavoidable today for plural schools, even if this will lead to take over the traditional reluctance to engage schools in "private issues". In fact, if religion is a "pending question" for young people, education must 
provide some replies. As Meuret (2015) argued, in order to contrast young people's fascination for ideological and religious radicalism, democratic education, as well as the republican one, have the specific task to teach students tolerance and civicness facing multi-religiosity. Youngsters can profit mainly from the school experience, if they want to learn how to gain (and not to lose) from religious diversity and how (and why) to avoid the main inconvenient of xenophobia, religious phobia and intolerance. Education in multi-religious settings can really open students towards a "non-relativistic view" and create in them a "value-sensitive attitude" (Pace, 2004: 279).

In the next paragraphs, after a brief overview on the secularized school environment in Europe, we will emphasize the role of religious education in the institutional frame $(\$ 2)$. Then, we will mention the state of religious education $(\mathrm{RE})$ in Italy, both in socio-demographic (what kind and how many students ask for $\mathrm{RE}$ ) and in normative terms (how the access to $\mathrm{RE}$ in public schools is regulated) (\$3). Afterwards, we will discuss the different approaches to interethnic dialogue in the Italian mixed schools $(\S 4)$. We will close the chapter by presenting the main theoretical and methodological assumptions of an empirical study focusing on the religious dimension of interethnic relationships in public education system, which was carried out during s.y. 2016/17 in lower secondary state schools in Northern Italy $(\$ 5)$.

The Secularized School Environment in Europe: What Is Religious Education Expected To Do?

The transformation of school environment in an increasing secularized setting (see Chapter 3) has to do with the reciprocal implications between state, education and religion, three fundamental institutions of the European civil society. Although with diverse nuances, at the turn of the millennium the process of de-institutionalization affected every organizations: the consequence has been a widespread suspicion and mistrust by people towards all kinds of formal guarantee -in the domain of social, economic and cultural or religious right's protection, the strongest opposition being against the political institutions. Since religion and education have a political side (although it may be non-visible to users), they could not avoid to be affected by this "institutional crisis".

Secularization began to be a feature of the modern education system long before the creation of a European space for education, as it is rooted in the Enlightening period. Anyway, it was during the 2oth century that the rationalistic school systems were established, and they regulated the spaces devoted to religious education, according to every national history and religious or 
cultural tradition. ${ }^{1}$ As Schreiner argues (2009; 2013), there are different religious landscapes in Europe. The South tends to be dominated by Catholicism (Austria, Italy, Spain, Portugal, Malta and to some extent France, as well as Poland, Ireland and Lithuania), whereas the North is more Lutheran-Protestant (Scandinavia). Central European countries tend to have mixed religious landscapes (Germany, Hungary, the Netherlands, etc.), while Orthodoxy dominates most countries in Eastern Europe, including Greece and Cipro. Finally, Islam is the major religion in countries like Turkey, Albania and Bosnia-Herzegovina.

Of course, the way in which the majority religion is followed, and taught in public schools, depends on the relation between state and religious authorities, state and education system and, finally, on the characteristics of education offer. It is not the case to compare all these elements. It is worth remembering, however, that multi-religiosity has had, and still has, different impacts on Member States, with direct implications on the cultural phenomena that I will analyze: secularization and resurgence of religions (de-secularization or post-secularization) ${ }^{2}$

According to many, secularization has different ways to be embodied and expressed by both institutions and lay people. On the institutional side, keeping the public school system as an example, secularization implies not only adopting a non-religious (or secular) curriculum, but also having looser relations with religious authorities (at a local and larger scale) and avoiding to let students practicing worships or celebrating religious ceremonies in the school space (including to forbid to wear religious symbols and clothes). On the personal side, secularization goes hand in hand with the decline of religious service attendance among youngsters (a sort of disaffiliation from religion) (Bertrand, 2015) and, more generally, the tolerance towards who is non-believer, or the idea that the condition of a believer is not necessarily superior to that of a non-believer. Both stand at the same level of importance and have the capacity to cope with the fundamentals in life (Garelli, 2016), provided that they are free to choose their beliefs.

1 As Casanova wrote: "Internal differences notwithstanding, Western European societies are deeply secular societies, shaped by the hegemonic knowledge regime of secularism" (Casanova, 2007: 62).

2 In the Humanities and Social Sciences field, many scholars advocate that religion has gained a new role in the globalized and plural society; after the "dogmatic secularism" imposed by the Enlightening, and after refusing the State religion, contemporary men still need a system of beliefs to follow, which justifies all the efforts to progress. Thus, for many, faith and religious observance become the response to this post-secular need, if chosen in a free and private regime (Berger, 1999; Habermas, 2006; Rosati, Stoeckl, 2012; De Kesel, 2017). 
Without doubt, in all Western countries the separation between state and church authorities, along with the affirmation of universalism of rights as a basic principle for the nation, have reduced the public role of religion in many spheres, i.e. in public education. This had some consequences, as religion may be a neglected and controversial topic, and laicism or neutrality may affect the way in which students, teachers and parents construct the discourse about religion in education. At the same time, in a liberal society public education does not derogate from its civic mission: promoting religious literacy and tolerance, and protecting individual and minority religious liberty, which are among the greatest challenges facing pluralism. How do public schools afford this dilemma on the ground?

In USA and Canada (two good examples of secularized and multi-cultural nation), schools typically adopt two different and extreme solutions: ( 1 ) making schools hyper-secular and potentially hostile to religion and religious believers, or (2) promoting either flagrantly or subtly the dominant religion of the local community, by adopting curricula that give the impression that any religion is inherently good (Bindewald et al., 2017). Nevertheless, none of the solutions have been successful: although they act within "a solid legal framework to protect the rights of students, the reality on the ground is that many schools are failing to live up to their obligations to students" (Ibidem: 18). The middle-path between the two extremes would be what the provinces of Ontario and Quebec, for example, carried out: "Enhancing students' religious literacy and engagement with the religious/cultural other - paying heed to warnings about not allowing majority groups to take advantage of religious education programs (...) or discriminating against minorities in the public schools" (Ibidem: 28).

In Europe the effects of secularization are deep and differ according to each country. A range of approaches to provide religion education have been adopted thanks to the initiative of different providers (religious communities, or the state or both). According to Schreiner (2009) and Ferrari S. (2013), the main distinction must be drawn among the following formula:

1) Learning from religion: countries where no teaching of one or more specific religions is offered, because references to religion are part of the corpus of other disciplines; this secular teaching is organized by state authorities exclusively (like in France, Czech Republic, Sweden, Belarus and Hungary);

2) Learning religion (or into religion): in many countries there is a confessional/catechetical approach, where $\mathrm{RE}$ is provided by religious communities that have the exclusive responsibility for teachers, textbooks and curricula: this is called "denominational" teaching of religion, 
(as in Austria, Poland, Spain and Italy); it is compulsory but in some cases students can opt out;

3) Learning about religion: $\mathrm{RE}$ is taught as a voluntary and/or mandatory subject in state schools and provides knowledge and information about a number of different religions from a point of view that is external to each of them; activities are fully in charge of the State, which pays for teachers, organizes curricula and checks for textbooks (i.e. in Slovenia: Kodeljia, 2012). $\mathrm{RE}$ is called "non-denominational" education and sometimes is taught collaboration with religious authorities (for instance, in the UK and Denmark).

Beyond the single pedagogical strategy, all kinds of RE find their legitimation in the attempt to respond to the new needs of young generations by facing multi-culturalism and secularization. This becomes more urgent in the countries where RE is denominational. In a "Europeanized" curriculum (Bekemans, 2013), Religion Education (even the denominational one) must be rooted not only in an academic and theological justification, but also in the search for a common understanding of religion as a social fact, mixing historical and philosophical elements of knowledge. This is the only "antidote against the threats of fundamentalism, on the one hand, or the 'big blank' of the laicism, on the other" (Pajer, 2009). The same purpose has been expressed by the Council of Europe in the Recommendation no. 1720 (Religion \& Education, 2005): "By teaching children the history and philosophy of the main religions with restraint and objectivity, and with respect for the values of the European Convention on Human Rights, it will effectively combat fanaticism. Understanding the history of political conflicts in the name of religion is essential". This document addresses some issues previously emphasized by the Parliamentary Assembly in 1999 (see Religion \& Democracy), ${ }^{3}$ which recommended that all State members provided in public schools any sort of religion education, both denominational and non-denominational, on a mandatory basis.

Strong support to this approach comes even from ODIHR-OSCE, whose Expert Group on Freedom of religion set up an important list of recommendations in 2007, the Toledo Guiding Principles (ODIHR-OSCE, 2007). They stated that: $a$ ) there is a positive value in teaching religion that must emphasize respect for every religion and belief; $b$ ) teaching about religions and beliefs can reduce misunderstandings and simplifications in facing the beliefs of others.

The traditional way to teach religion subjects, as doctrine transmission and preparation to worships, has been hardly discussed and reformed in many

3 Resolution adopted by the Assembly on 27 January 1999 (5th Sitting). See: http://assembly .coe.int/nw/xml/XRef/Xref-XML2HTML-en.asp?fileid=16672\&lang=en. 
countries. What is urgent now is to give people of the globalized 21st century not only reasons to reinforce one's identity and choice, but also the widest cognitive and ethic potential to "get" a religious culture with freedom and awareness. The perspective to assume is thus interdisciplinary and intercultural: religious education embodies both religious and moral convictions; these are gradually taken from the subject along the life course, and are based more on real social and personal experiences than on the family heritage; the school approach must integrate spiritual, moral, ethical and civic values (Council of Europe, 2006).

In conclusion, the role that $\mathrm{RE}$ is expected to play in the European secularized and multi-cultural landscape is multiple: $a$ ) to give pupils a religious literacy in their own and others' religion; $b$ ) to instill the rational and critical thinking facing religious issues; $c$ ) to reinforce social cohesion by recognizing that belonging to a religion is a fundamental "identity marker" among others; d) to offer exemplary patterns of social coexistence among diverse people.

As a matter of fact, these are very challenging objectives in many countries. RE still remains a "slippery arena of education" (Benadusi et al., 2017:476) because of the implicitness of many issues that it raises up: equality and right of difference; visibility and invisibility of one's religious belonging; school autonomy and need of extra-school partnerships with confessional representatives, only to mention some of the main dilemmas.

Italy has greatly been affected by cultural diversity and plural religiosity as well, especially since the turn of Millennium. The country has a long tradition in $\mathrm{RE}$, for the teaching of one religion, i.e. Roman Catholicism, which is the majority religion. The teaching of the Catholic religion is called IRC (Insegnamento della religione cattolica). Despite the nation has strong Catholic roots, education is by $90 \%$ provided by the State; in addition, $7.5 \%$ of private schools are coordinated by the Catholic Church with the support of the State. ${ }^{4}$

According to the agreement signed in 1922 by Italy and the Holy Church and renewed in 1984 (Chapter 9), in all state schools, IRC is guaranteed from the

4 Law n. 62 of 2000 establishes that private schools can be recognized on an equal basis with State schools, in accordance with Article 33.4 of the Italian Constitution, if they comply with some requisites (about programs, teachers, etc.). In this case, they are called scuole paritarie. They are publicly subsidized; they also have the authority to issue certificates with the same legal value as qualifications from State schools. Most of the Catholic schools in Italy are classified as "paritarie". 
infant school to upper secondary education for one hour per week (two hours only in kindergarten and pre-school services) and it is funded by the State. The IRC is taught by class teachers, if they are available and considered appropriate by the Catholic Church authority (CEI - Conferenza Episcopale Italiana - Italian Episcopal Conference), or by special teachers, selected and prepared by the CEI itself.

Until the 1980s, IRC was a "compulsory discipline, from which parents were allowed to withdraw their children" (Giorda, 2015: 80) in case they disagreed with a confessional education or they were non-believers. In other words, as Coglievina says (2017: 2): "As Catholicism shaped Italian national identity, the presence of Catholic religion lessons in the state-school system has been regarded as something 'normal'. Nonetheless, in 1984, after a strong and confrontational debate developed in many political and cultural environments, the renewal of the Concordate introduced a new type of student's engagement: parents were requested to subscribe IRC at the beginning of school cycle. For those who do not opt for IRC, the regulation offers several options: an "alternative activity" (AA) established by the school itself, which should address topics concerning ethics, values, tolerance and peace. ${ }^{5}$ This activity should be imparted by any teacher who is, at the time, available. Another option is tutoring (revision, in-depth studying) or, for high school, a study activity without the presence of any teacher, within the school premises; lastly, an often selected option is the early exit from school (or delayed entry).

Due to the history of the country as mono-confessional, the opening of an alternative education to teaching of one religion represents an official acknowledgment of religious pluralism: in public and state schools, there is an amount of children coming from families with different views or practices concerning religion. Thus, $\mathrm{RE}$ is asked to meet the challenge of secularization and religious plurality and the multiple needs of a secularized and multi-faith student body.

As a consequence of the new choice regime, the number of students who followed IRC during the ordinary school time has decreased, even if the vast majority still opt for it (the provision of IRC is guaranteed in every school no matter of how many students subscribe). The Catholic Church office for IRC (Servizio Nazionale CEI per l'IRC, 2016; 2015) shows this trend: in s.y. 2015/16, the subscribers to IRC in the state school system (all degrees) were $87.9 \%$ out of the total (81.5\% in upper secondary education). Since s.y. 1993/94, this proportion has decreased by $-5.6 \%$. In the private school system, the participation to IRC is much higher than in the public one, being most of private schools

5 See the Ministry of Education Circular Letters, No. 128, 129, 131 (1986). 
run by Catholic organizations: $97 \%$ of the private school population opt for IRC and only $3 \%$ for alternative activity (AA).

As a matter of fact, AA have been little and badly organized so far, even because they have been optioned by a minority of students (12.1\%); someone argues it is still an "invisible education" because, by ministerial rules, it is not requested to be planned and included in the PтOF (the 3 -year general education plan of one school). This explains its inferior status in comparison with the rest of school subjects and, consequently, it reduces the legitimation of the student's choice between RE or AA (Bossi, 2017). If a non-choice could be a little problem for natives (whose majority opt for IRC), it can be considered as a falsification or a lack of freedom of choice by immigrant students (amongst whom, almost $20 \%$ are Catholic). As shown by the Istat research on Religious belonging and practice among foreign citizens (2011-12), 60.4\% of immigrants in Italy between 6 and 17 years old attending Italian schools do not belong to the Catholic religion (Istat, 2015). The majority are Muslim (30\%), followed by Catholic (23.2\%), Orthodox (19.6\%) and, at a distance, Buddhist (3.6\%) and Protestant $(2.4 \%)$ and others. ${ }^{6}$

Therefore, the multi-ethnic composition of the classrooms (especially in the North of country) radically changes the "religious profile" of a school or group of students: not all are believers; not all believers are observant; not all believers have a mono-religion family background, etc. In a past study on low secondary multi-ethnic schools in Lombardy (Colombo, Santagati, 2017; Santagati et al., 2019), with $39 \%$ average rate of non-Italian students), the sample was distributed as follows: $11 \%$ were not believers; $89 \%$ believers; within believers, $3 / 4$ were Catholic and $1 / 4$ minority religions; $3 / 4$ were observant but $1 / 4$ (both Catholic and non-Catholic) were non-observant.

Thus, in the last decade, a fundamental reforming process of the IRC teaching has been activated, both by the CEI and the whole body of IRC teachers. They have become aware of the multi-faith change of school population, which affects the attendance of IRC both quantitatively and qualitatively. The challenge of secularism is also becoming day by day more acute.

From the one side, students of foreign origin bear a religious belonging and a family tradition (according to which religion must be respected as a belief, a worship, and a concrete authority performed by parents or community representatives) and emphasize the identity meaning of religion. If non-Catholic,

6 For distribution of non-Italians according to their religion, see also Idos, 2018: 196, and Ismu Foundation, 2018. Idos estimates that among foreigners 33\% is Muslim; $30 \%$ Orthodox; $18 \%$ Catholic; $4.5 \%$ Protestants; $3 \%$ Induist: $2.5 \%$ Induist, $0.1 \%$ Hebrew; $1.6 \%$ Sikh and other Eastern faiths; and $5 \%$ atheist or agnostic. 
they do not attend IRC, because it is considered as "an hour of other people's religion" (Frisina, 2011: 275). In this way, they reinforce the religious and cultural divide between believers of different origins: seen as a narrow confessional education, IRC ends up going far from the article 9 of the Concordat, which states that the teaching of Catholic religion in state schools (according to the secular nature of the State) must be "part of the aims of the education system" and consequently cannot coincide with catechism, but it must be open to pluralism and take a cultural-historical perspective.

From the other side, native students attend IRC for a range of motivations, not always spiritual or authentically religious, but often practical, opportunistic, and superficial - which tends to diminish the importance and seriousness of IRC itself. ${ }^{7}$ This is due to the increasing secularism, or laicism, or "flexible Catholicism" among Italian population, as Garelli $(2011,2012)$ pointed out, that is a widespread affiliation to Christianity associated to a secular behavior and discontinuous presence in ecclesial settings. Among Italian young people, a "cold" attitude towards religion and personal engagement in worship is very common, and it is called "occasional Catholicism" (Grassi, 2006: 60).

To remark the weakness of the IRC (Canta, 1999), it is also worth mentioning that IRC teachers are considered by students and parents as less authoritative than other professors; moreover, their professional status is more precarious in comparison with the rest of the teaching staff (Silhol, 2017).

To sum it up, as of today, IRC must meet a double-face challenge:

a) to reinforce and legitimate its status, balancing believer and non-believer students' needs in the light of a "national way to secularism" (Garelli, 2011; Canta et al., 2011), and

b) to help any religion to take voice in public spaces according to ecumenism and post-secular societal needs (which requires that a discourse on God must be carried out and not bypassed, even in affluent and fully secularized societies $\left.{ }^{8}\right)$.

In particular, RE is a sensitive and "heated" matter in the everyday life of school. The initiatives introduced by IRC teachers outside the classroom (i.e. celebrations, projects, campaigns etc.) meet the disagreement of atheist representatives, who claim for a secular education according to the Constitutional right of freedom of belief and nurture a long-standing debate with many political repercussions on the status of $\mathrm{RE}$ in public schools (Giorda, 2015). However, the presence of religions other than Catholicism among the student

7 Mentasti and Ottaviano (2009: 243) spoke about a "lukewarm" participation to IRC in a sample of upper secondary students surveyed in 2006.

8 On the post-secular societal needs, see: Rizzi, 2016. 
population is not easy to manage and, often, it is up to IRC professors to deal with it. Generally speaking, multi-religiosity is not emphasized or stigmatized in Italian public schools: rather it's ignored and minimized. ${ }^{9}$ There is very limited room for minority religions (Ferrari A., 2013b), so that sometimes nonCatholic migrant pupils do attend IRC (especially those coming from an Orthodox, Protestant, and sometimes even Islamic family), when parents agree if their children get some information about religion instead of no religious information at all (or they attend classes against their parent's wishes) (Frisina, 2011: 276). In these cases, IRC becomes a "space of presentation and mediation" between diverse habits, beliefs and traditions.

Because of these facts, the need to renew RE in public schools has become urgent in order, firstly, to cultivate a type of education, which renews the sense of RE for dubitative or superficial Catholic offspring. Secondly, to give room to other narratives of God (and spiritual positions) coming from minority believers, whose sense of belonging to their own religion is often stronger than the one Catholics have. RE addresses both minority and majority followers (and atheists too) in order to raise awareness of the risks of fundamentalism and to educated in the practicing of dialogue. Consequently both IRC and secular curricula, in the last few decades have begun to focus on active citizenship, communication about religion and interreligious dialogue (Vacchiano, 2013), as new fields of engagement for RE scholars and teachers (Bradford Local Authority, 2016; Salvarani, 2006).

\section{Different Approaches to Interreligious Dialogue in the Italian Mixed Schools}

On the future of RE in Italy within the frame of intercultural education, an intensive cultural debate has been developed in the last decades, involving politicians, Church representatives, academic experts, etc. An even higher number of Italians ask for a change in denominational $\mathrm{RE}$ in public schools, despite they do not want to delete IRC (Garelli, 2011: 171-4). Giorda (2015: 91) states that "This country offers a special and original focus to consider the ambiguity of unsolved tensions between the authority and the Constitutional privilege of one Church, the secularism of the juridical frame and the plural and superdiverse reality". It is not surprising, then, if at a national and institutional level,

9 For example, non-Catholic students can opt out from IRC, but they cannot have a parallel confessional education during the school time. 
the public debate brought about only few concrete consequences..$^{10}$ However, in many local realities affected by this debate and moved by a spirit of renewal, new pluralistic strategies have been adopted in RE provision - some temporary and experimental, some more structured.

Many providers agree on two fundamental principles, useful to bypass prejudices and discriminations among students of different beliefs: $a$ ) knowledge about religion is necessary for anyone, believers and non-believers; $b$ ) confrontation among different beliefs must occur in a free and democratic educational setting (Pinto Minerva, 2012). By consequence RE, no matter if denominational or non-denominational, must be rooted on the universal values of men and women, drawn from the European Union Chart of Values, and must train the basic citizenship competences in every (future) citizen (Halász, Michel, 2011).

In fact, RE helps to reach a European integration, and must refuse any method or content that could end up separating, isolating, or segregating individuals on the basis of their religion, or that creates intergroup conflicts. Knowing one's own religion, or others' religion, is considered to be fundamental for a full maturation of the person and for a peaceful coexistence between diverse people. On the contrary, ignorance and illiteracy, neglecting and neutrality facing religion issues are considered as factors of social disorder (Council of Europe, 2008;1 Wierzbicki, 2016). This kind of preparation to diversity must occur in a secular environment, based on freedom of thought, conscience and religion, in which diverse religious beliefs are welcome, but none should have the prominence on others. This is the necessary premise facing the risk that -among immigrant people- Islam would become the first minority religion by number of followers and take advantage of other faiths, limiting the freedom of expression of other beliefs..$^{12}$

10 For example, from about 2000 to now, a heated debate has been developed on the laicity in Italian schools, that is, the correctness of exposing religious signs in state schools (i.e. Crucifix), or imposing food regimes or religious celebrations to minority students (this echoed the laicism adopted in France with the "no-veil legislation" in 2003). See the mention to "Ofena case" in Ottaviano, 2010. The issues at stake were: $a$ ) the way in which the secular nature of public institutions would be guaranteed, and $b$ ) the safeguarding of the right of free expression for every religion. At the end of a large debate, legislative changes have taken place.

11 Intercultural and interreligious dialogue, as a means to foster democracy and prevent social conflicts, is an idea emphasized by the White paper on Intercultural dialogue in Europe (Council of Europe, 2008: 4): "It contributes to strengthening democratic stability and to the fight against prejudice and stereotypes in public life and political discourse and to facilitating coalition-building across diverse cultural and religious communities, and can thereby help to prevent or de-escalate conflicts - including in situations of post conflict and "frozen conflicts"'.

12 Although Islam is the majority faith followed by foreign citizens, in Italy the risk of "Islamization" is far from the truth. Nevertheless, many authors report that native parents 
Several authors and studies report experimental activities of interreligious dialogue, carried out both within and outside IRC in Italian multi-cultural schools. All attempts are embodied in one of the three landscapes, designed by Canta $(2006,2013$ b).

1) Religious Pluralism: beyond IRC (which remains unaltered, addressed to Catholics), other denominational teaching of religions could be offered to non-Catholic students as a curricular activity, according to specific agreements signed by the State and the single Churches. An alternative activity (AA) for atheist and agnostic students must be provided as well, to guarantee equity in the school offer, teaching "religious issues", such as ethics, history of religions, religious culture.

2) Interreligious curriculum: with the compliance of ecclesial authority, IRC could addresses all learners (who opt for IRC and who do not), teaching the basic elements not only of Christianism but also of other faiths; i.e. the three monotheisms (Christianism, Hebraism and Islam) or some of Mediterranean faiths, or those religions that are represented in the school population.

3) "Understanding Islam" Laboratory: within IRC curriculum, Catholic religion teachers can be prepared to teach some learning modules devoted to understanding Islam (of course, this module cannot be confessional). The aim of this proposal is multiple: to make Catholics aware of the historical and cultural contribution given by the Islamic religion to Europe; to prevent the diffusion of religious prejudices towards Muslims (islamophobia) among native students; to prevent the formation of radicalized visions of Islam among children of Muslim immigrants; to involve Muslim students in participating at IRC as witnesses of their own religion; and to implement a "laboratory" of interreligious dialogue, although this cannot universalistic (and participation of IRC remains optional).

To mention only a few exemplary experiences, the first scenario is underpinned by what Giorda (2013) reports: in a Waldesian Lyceum (Torre Pellice, Piedmont), since 1984, a 5-year mandatory course of History of Religions, associated to that of Local History, ${ }^{13}$ has been carried out. Both have been considered as complementary subjects to general history, and attended by both Waldensian and non-Waldensian pupils, believers and non-believers. "The

express an increasing islamophobia (especially after the 11th of September 2001), associating Islam to fanaticism, fundamentalism, intolerance and ethnocentrism, and this prejudice look higher towards Muslim Middle-Eastern people (Santerini, 2008; Branca, Cuciniello, 2014).

13 This course was activated in collaboration with the local archive and library of Waldensian Society of Studies. 
course, which features a historical approach and integrates the normal course of history, aims to teach the principal founding elements of the ancient religions of the Mediterranean (...) and of the religions of the present-day world; there are presentations of the Bible and the Koran (Giorda, 2013: 185). Learners are expected to understand "the main differences between religions, and to learn about the relationship between religion and culture of people throughout history" (Ibidem).

Within the second landscape, a number of experimental curricula of $\mathrm{RE}$ based on historical and comparative approach has been put in place in many Italian high schools (i.e. in Bari, Turin, Verona and Rome), often in collaboration with Departments of Religious studies and academic staff of the local universities, local ministerial offices, NGOs and municipalities. Salvarani (2008) reports the experience named Bible Educational, aimed at widening the knowledge of the Bible beyond the Catholic students; it is a project carried out in many secondary schools (in 2006-2008) with the aid of the Ministry of Education and several private foundations. ${ }^{14}$

However, before introducing an interreligious curriculum, there is the need to compensate the low preparation of ordinary teachers with external competences (which must come from both university and confessional agencies) (Rispoli, Giorda, 2016; Naso, 2013). When teachers are not prepared enough, or they have no textbooks and bibliography updated with the extracts from the Sacred texts of all religions, the experiment ends up being too specific and the school as a whole does not change, does not learn from the didactic innovation (Mentasti, Ottaviano, 2008). The main tendency, monitored in Italy, is the minimization of religious plurality: the majority of teachers underestimate the influence of religions in the classroom (Daher et al., 2016), and the potential of conflict underpinning the tacit non-consideration of other religions. In this way, the interreligious dialogue cannot proceed and teachers have to cope with the interfaith or intrafaith conflicts without appropriate tools (Daher et al., 2017).

One other interesting innovation in IRC provisions is the activity aiming at understanding Islam (third landscape). Since 2005, several NGOs and experts in Islam-Christianity Dialogue have been committed to preparing didactic materials in order to provide teachers with correct information about Islam, even in collaboration with the Faculties and Departments of Islamology (Bargellini, Frascoli, 2005; Bargellini, Cicciarelli, 2007; Canta, 2013b; Cuciniello,

14 See: www.bibbiaeducational.org. Other projects are reported in: Clementi, 2008. 
2017a). The first purpose is to lead Catholic students not to perceive Islam as an "archaeological" and uninvolved civility (according to a "synchronic approach") and to transmit a more adequate representation of Islamic culture and societies, as: $a$ ) connected with the European history, and $b$ ) embraced by a multisegmented, non-monolithic population. A wider and modern view of Islam should include not only historical and territorial conquests, but also scientific and cultural innovations. Thus after a deconstructive analysis of traditional textbooks a re-construction of what is said and written about Islam in regular lessons has become a fundamental part of the new way to "understand Islam".

In the previous paragraphs we described how RE, multi-religiosity and secularism set up in Italian public schools. To sum it up there is a contradiction between the institutional and the "relational" school life:

- At institutional and formal level, almost all religious issues are attributed and regulated within the IRC frame (that is, teaching of one religion), as the rest of the subjects taught are "secular" or "neutral";

- Instead, at relational and informal level, religious issues are lived and questioned by pupils, teachers and parents in the ordinary school life, being the majority of school staff almost uniformed and non-prepared to manage them.

When religious bullying arises or even happens, the high level of tension among peers reveals the difficult management of multi-ethnic classes (Bergamaschi, 2016; Colombo, Santagati, 2017). Even the recent violence and radicalism within the second generation of immigrants tells us the same (Gambetta, Hertog, 2016), although this violence does not always occur within the school, as much as outside the school (Santagati et al., 2017). The persistence of the juvenile need to be identified (and distinguished) not only by name, family background, local and cultural roots, but also by the religious community the children/youngsters belong to, is a push for deep reflection for sociologists of education (Cipriani, Costa, 2015). It requires exploring:

a) the student's point of view,

b) that of parents/teachers, and

c) the public/institutional perspective (Rowe, 2016).

Because of this, an empirical study has been carried out with the aim of exploring the religious dimension of interethnic relationships in public schools. The analysis of religions in public schooling is associated to both the presence of 
second-generation immigrants (who can get citizenship by law only at 18, unless their parents have naturalized thus transmitted Italian citizenship to their minor-aged children) and the perspective of interreligious dialogue, that is, religious pluralism is seen as a push factor for RE renewal (Halafoff et al., 2015).

The major aim of the field enquiry is analyzing how (and in which forms) religion is a relevant dimension within the interethnic dynamics in the school context, both in vertical relationships (teacher-students) and horizontal relationships (among peers).

The theoretical frame of research embeds religion in a system of interdependency between four key dimensions: Identity (I), Freedom (F), Citizenship (C) and Common good (CG) (see Chapter 2). For native and immigrant population, the religious belief has an impact on each of these dimensions, affecting both the individual and the collective life. Thus it is worth wondering: does the religious faith influence the process of Self-shaping? (I); how much can people practice a given religion freely within an institution or a social group? (F); how does a given religion affect the access to legal citizenship for the group of followers? (C); what is the contribution of religiosity to the civic consciousness (religion as a cultural heritage)? (CG), and so on.

In the school environment, the four key dimensions lead to more specific questions, such as:

- How does pupil's and adult's religion become an element for self-identification, self-expression and affirmation in intergroup exchanges? What kind of frictions or conflicts do the different cultural and religious identities bring about in the school environment?

- (F) Are teachers and students feeling free to express their own religious beliefs at school? How much is the attendance of IRC classes freely chosen or, instead, imposed by parents among both majority and minority students? Are the religious prohibitions of school activities (among immigrant students) an expression of their freedom of choice or a parent imposition? Is the freedom of expression about one's own religion limited or negatively affected by prejudices, jokes, teasing or bullying among peers?

- (C) Is religion conceived by both young people and adults as a private or public matter? Are the non-Italian nationals affected by minority status, also due to their religious faith, as far as their sense of belonging and their school integration are concerned?

- (CG) Are the minority religions represented enough in the school curriculum? Can the whole school population correctly understand the contribution of a single religion to the current national and European common identity? 
Our general hypothesis says that, despite religion is often considered as a reason for social conflicts and xenophobia in secularized society, in the school environment students' religious beliefs and values (if expressed in a regulated, welcoming and accommodating institutional setting) could be positive factors for the social integration process as a whole. In fact, religious socialization provided by family, school and confessional community might reinforce one's own sense of identity and the will of integration by enlarging the social capital necessary for the growing process of pupils (Coleman, 1988). This applies both to native and immigrant children.

Through the medium of self-reports, collected by pupils, teachers and parents, we can observe, firstly (Chapter 22), how (and in which forms) the religious belonging of the different social actors is visible and expressed in the school environment, rather than hidden and neglected. In particular, we want to verify if the "freedom of choice and expression" (as a Constitutional principle) applies to the religious needs and sensitivity of people who attend public education in a multi-ethnic and multi-cultural situation. We expect to draw findings about:

a) Existence (or non-existence) of an open debate around the minority pupils' rights in schooling according to their religious convictions;

b) Different ways by which religion (or atheism) affects students' behavior and attitudes;

c) Different patterns in the school-family link about religious matters, possible impediments or discriminatory behavior towards minorities (put in place by either teachers or peers), chances and opportunities generated by interreligious dialogue;

d) Different ways in which the school curriculum, and particularly the IRC curriculum, deal with multi-religiosity the classroom.

Secondly (Chapter 23), we want to analyze religion as a triggering factor of interethnic exchanges in schools, by wondering:

- Does religion play the role of "precipitating factor" of conflicts, being a source of problems and tensions, generally seen as the marker of diversity and social divide (Foner, Alba, 2008)?

- Or, on the contrary, is it a bridge for inclusion, a "facilitating factor" of the adaptation process of immigrant offspring?

Previous European studies on the same topic came to different conclusions: someone found out that educational integration is facilitated by the disappearance of religious identity (Esser, 2010); someone else stated that, in some cases, religiosity is compatible with integration, if the receiving school contexts are welcoming enough and try to accommodate religious 
diversity (Flieschmann, Phalet, 2012). In our study, we expect to draw findings about:

a) Different kinds of conflict (on the basis of religion) among peers and between teachers and students, or teachers and parents, in multi-cultural classrooms and how they generate, develop, spread with specific attention paid to words, attitudes and behavior adopted by social actors;

b) Different narratives on religious tensions, made by teachers, native and foreign students, native and foreign parents;

c) Ways to manage religious conflicts from the perspective of school institution and professors;

d) Explanations of religious-based conflicts from the different point of views of adults and preadolescents.

Of course, we will consider the backdrop of the possible conflicts in multicultural classroom, that is, the wider social disadvantage of immigrant children, due to the economic and cultural divide with native population, in which the religious difference covers only a part of the problem (Santagati, 2015; Ricucci, 2017). Several studies highlight the combination between multiple constraints and factors of disadvantage (the so-called intersectionality) (Crenshaw, 1989), such as age, race, ethnicity, gender, sexuality, class, cultural capital, living place, etc. According to the intersectionality framework, the interplay between structural and cultural factors brings about boundaries and hierarchies in social life, mostly beyond the individual efforts. Thus an empirical study on disadvantage categories and subjects should have the sensitivity for the issue of power and it should locate the social practice within given spatial and temporal contexts (Anthias, 2013).

As far as the methodology is concerned, the field enquiry was carried out in spring-summer 2017 in lower secondary state schools (compulsory education) located in Lombardy (Italy): Milan, Brescia, and Bergamo. ${ }^{15}$ The target population was made up of a sample of low secondary students (11 to 14 years old), some of their parents, and a selected group of secondary school teachers and principals. 14 focus groups have been carried out ( 7 groups with students and 7 with adults) for a total of 74 students and 69 adults. Groups

15 The schools participating in the research are: IC Calcio (Province of Bergamo - BG); IC Ovest 2 Tridentina Brescia; IC Pralboino (Province of Brescia - BS); IC Polo est Lumezzane (BS); IC Terzani Abbiategrasso (Province of Milan - MI); IC Palestro Abbiategrasso (MI); IC Aldo Moro Abbiategrasso (Mi); IC Borsi-Ojetti Milano; IC Primo Levi Baggio Milano. We are grateful to all participants and their school representatives for the serious and precious engagement in the study. 
were composed of believers of different religions and non-believer persons (atheist or sceptical): see Tables 21.1-21.2 for the participants' composition.

A semi-structured grid of questions has been administered to each group of discussion (lasting 1.30 to 2.30 hours), based on similar inputs. All questions addressed to students and adults referred to the four key dimensions of the study (see above) and they tried to be as "two-fold" as possible: the same item was administered to both targets (youngsters and adults), with the necessary adjustments due to different languages and status. In Table 21.3, one can read the comparative list of questions.

All focus groups have been conducted and recorded by the same research staff. All transcripts have been processed by N-Vivo 11.o. Chapters 22 and 23 will present some of the research findings about the main objectives of enquiry.

After these, two concluding chapters will host the analysis of the multi-religiosity schooling link respectively in France (Chapter 24) and Spain (Chapter 25), two European countries whose history of migrations and public education systems are of interesting comparison with Italy. From a cross-national comparison, the reader will learn how much Italy differs on:

a) the implementation of secularization (which in France is part of the national identity) in public education;

b) the cultural diversity management within the earlier stages of public education, included the RE curriculum which in Spain is under revision, due to the multi-religious composition of the classrooms in many places of immigration.

TABLE 21.1 Focus groups with students - participants' composition

\begin{tabular}{|c|c|c|c|c|c|c|c|c|c|c|c|}
\hline FG & N. & Females & Males & Italian & $\begin{array}{l}\text { Non- } \\
\text { Italian }\end{array}$ & Catholics & Muslims & $\begin{array}{l}\text { Orthodox } \\
\text { Christians }\end{array}$ & Sikhs & $\begin{array}{l}\text { Hin- } \\
\text { dus }\end{array}$ & $\begin{array}{l}\text { Bud- } \\
\text { dhists }\end{array}$ \\
\hline $1 \mathrm{BS}$ & 14 & 8 & 6 & 7 & 7 & 7 & 6 & 1 & 0 & o & 0 \\
\hline $2 \mathrm{BS}$ & 7 & 4 & 3 & 2 & 5 & 2 & 1 & 0 & 2 & 2 & o \\
\hline 3 BS & 12 & 4 & 8 & 6 & 6 & 6 & 3 & 1 & o & 1 & 1 \\
\hline $4 \mathrm{BG}$ & 11 & 7 & 4 & 6 & 5 & 6 & 3 & o & 1 & 1 & o \\
\hline $5 \mathrm{MI}$ & 10 & 4 & 6 & 5 & 5 & 8 & 0 & 1 & o & o & 1 \\
\hline $6 \mathrm{MI}$ & 10 & 5 & 5 & 6 & 4 & 7 & 2 & o & o & 0 & 1 \\
\hline $7 \mathrm{MI}$ & 10 & 5 & 5 & 4 & 6 & 4 & 4 & 0 & 0 & o & 2 \\
\hline TOT & 74 & 37 & 37 & 36 & 38 & 40 & 19 & 3 & 3 & 4 & 5 \\
\hline
\end{tabular}

SOURCE: AUTHOR'S PERSONAL ELABORATION. 
TABLE 21.2 Focus groups with adults - participants' composition

\begin{tabular}{lccccccccc} 
FG & N. & Females & Males & Parents & Teachers & Principals & Italian & $\begin{array}{c}\text { Non- } \\
\text { Italian }\end{array}$ \\
& & & & & & & & & \\
1 BS & 13 & 13 & 0 & 7 & 5 & 1 & 9 & 4 & 10 \\
2 BS & 8 & 6 & 2 & 3 & 4 & 1 & 8 & 0 & 8 \\
3 BG & 13 & 6 & 7 & 5 & 7 & 1 & 11 & 2 & 11 \\
4 M I & 9 & 7 & 2 & 3 & 5 & 1 & 9 & 0 & 9 \\
5 MI & 9 & 6 & 3 & 4 & 4 & 1 & 7 & 2 & 8 \\
6 M I & 8 & 8 & 0 & 2 & 4 & 2 & 8 & 0 & 6 \\
7 M & 9 & 7 & 2 & 0 & 6 & 3 & 9 & 0 & 9 \\
TOT & 69 & 53 & 16 & 24 & 35 & 10 & 61 & 8 & 61 \\
\hline
\end{tabular}

SOURCE: AUTHOR'S PERSONAL ELABORATION.

TABLE 21.3 Items for focus group interview - reference to 4 keywords and comparison between targets

\begin{tabular}{ll}
$\begin{array}{l}\text { Prevailing Students } \\
\text { dimensions }\end{array}$ & Teachers-Parents \\
\hline
\end{tabular}

Identity What is their religious consciousness Agreement on "religion as and "literacy"? What do they do to make identity factor" (collection of their religion visible/invisible? opinions)

Freedom Which feelings are associated to the How/how much are religions expression of the minority or majority's expressed (or not) in the religion in the school context (I-F): $\quad$ school context? In which Muslim veil, Catholic crucifixes ...? forms? (collection of (collection of episodes)

How do they feel when coping with How do they feel when religious pluralism in the school? coping with religious pluralism in the school?

Citizenship What religion-based conflicts do they How does pupils' religion cope with and how do they manage take part or intervene in their them (pro and against who?)? $\quad$ educational relationships (collection of episodes) （collection of episodes)? 


\begin{tabular}{|c|c|c|}
\hline $\begin{array}{l}\text { Prevailing } \\
\text { dimensions }\end{array}$ & Students & Teachers-Parents \\
\hline \multirow{4}{*}{$\begin{array}{l}\text { Common } \\
\text { good }\end{array}$} & & $\begin{array}{l}\text { What kind of religion-based } \\
\text { conflicts do they cope with (if } \\
\text { rights and duties are at } \\
\text { stake)? }\end{array}$ \\
\hline & & How do they manage them? \\
\hline & $\begin{array}{l}\text { Do they think religion must be more or } \\
\text { less considered in the curriculum? }\end{array}$ & $\begin{array}{l}\text { Do they think religion must } \\
\text { be more or less considered in } \\
\text { the curriculum? }\end{array}$ \\
\hline & $\begin{array}{l}\text { How do they practice dialogue with } \\
\text { other religion observants? }\end{array}$ & $\begin{array}{l}\text { How do they practice } \\
\text { dialogue with other religion } \\
\text { observants? }\end{array}$ \\
\hline
\end{tabular}

SOURCE: AUTHOR'S PERSONAL ELABORATION.

In conclusion, we are convinced that the sociological look at the religion-immigration relationship in the school environment should develop a sensitivity about the main patterns of religious-based behavior in multi-cultural schools (including symbols usages). If school professionals would become competent to detect religious frictions and "religious bullying" among peers (along with a specific preparation in conflict management), they could recognize the multiple nuances of religious pluralism and the ways it can increase or hinder integration of minority pupils. In this way, there would be room to enhance the effectivity of their efforts towards civic and religious education in a frame of intercultural dialogue. 